June 1990

\title{
Neurodevelopmental Disorders Associated with Chromosome 15
}

Karl G. Sieg, M.D.

University of Kansas Medical Center

Follow this and additional works at: https://jdc.jefferson.edu/jeffjpsychiatry

Part of the Psychiatry Commons

Let us know how access to this document benefits you

\section{Recommended Citation}

Sieg, M.D., Karl G. (1990) "Neurodevelopmental Disorders Associated with Chromosome 15," Jefferson Journal of Psychiatry. Vol. 8 : Iss. 2 , Article 5.

DOI: https://doi.org/10.29046/JJP.008.2.002

Available at: https://jdc.jefferson.edu/jeffjpsychiatry/vol8/iss2/5

This Article is brought to you for free and open access by the Jefferson Digital Commons. The Jefferson Digital Commons is a service of Thomas Jefferson University's Center for Teaching and Learning (CTL). The Commons is a showcase for Jefferson books and journals, peer-reviewed scholarly publications, unique historical collections from the University archives, and teaching tools. The Jefferson Digital Commons allows researchers and interested readers anywhere in the world to learn about and keep up to date with Jefferson scholarship. This article has been accepted for inclusion in Jefferson Journal of Psychiatry by an authorized administrator of the Jefferson Digital Commons. For more information, please contact: JeffersonDigitalCommons@jefferson.edu. 


\title{
Neurodevelopmental Disorders Associated with Chromosome 15
}

\author{
Karl G. Sieg, M.D.
}

\begin{abstract}
Chromosome 15 is a focus of increasing interest to both psychiatry and neurology. Several neurodevelopmental disorders are genetically associated with this autosome, including Prader-Willi syndrome, Angelman syndrome, Dyslexia, Autism, Hyperlexia, Ring 15 Chromosome syndrome, and Trisomy 15 syndrome. This report provides a review of the molecular biology of chromosome 15 and these associated disorders.
\end{abstract}

\section{INTRODUCTION}

Genetic research provides important information for the understanding of many disease entities. By defining an underlying genetic abnormality, a comprehensive understanding of the nature of certain disorders is possible. One particular autosome associated with a wealth of genetic research is chromosome 15. New advances in detecting chromosomal abnormalities have clearly related this autosome to several specific disorders characterized predominantly by pathologic neurodevelopment.

\section{THE MOLECULAR BIOLOGY OF CHROMOSOME 15}

Chromosome 15 is an acrocentric chromosome that comprises nearly $3 \%$ of the total human haploid genome (1). It is laden with satellite rich, heterochromatic, centromeric stalk regions which interfere with meiotic cross-over and preserve linkage groups in regions near the centromere (2). During meiosis, chromosome $15 \mathrm{~s}$ pair like other $\mathrm{D}$ group chromosomes and form chiasmata in the proximal region of the long arm as well as at the telomere providing opportunities for unequal crossing over. Heterochromatic heteromorphisms are postulated to be the result of interspersed satellite DNAs composed of short repetitious sequences (3). The palindromic sequences contribute to instability of the region $(4,5)$. The proximal long arm is thus commonly associated with translocations, small bi-satellited chromosomes (SBAs), and deletions. Addi-

Address correspondence to Dr. Sieg, Division of Child and Adolescent Psychiatry, University of Kansas Medical Center, 39th and Rainbow Blvd., Kansas City, KS 66103. 
tional research differentiates chromosome 15 from other morphologically similar acrocentric chromosomes on the basis of high levels of 5-methylcytosine-rich DNA (6). These sequences are uncharacteristically rich in adenine-thymine base pairs as highly methylated base pairs of other chromosomes are rich in guaninecytosine base pairs. This gives chromosome 15 a unique chemical composition which accounts for its bright fluorescence after DA/DAPI staining (7). These features all likely contribute to the increased frequency of structural alterations during DNA replication.

As of 1990, 118 loci are assigned to chromosome 15, and 84 of these are regionally mapped (8). 47 are classified as genes with 37 restriction fragment length polymorphisms described in relation to the $71 \mathrm{DNA}$ segments isolated from this chromosome. There is one aphidocolin-type fragile site at $15 \mathrm{q} 22$. A number of these genes are associated with specific medical disorders. The gene encoding the human cholesterol side chain cleavage enzyme cytochrome P450SSC is present (9). Abnormality of this enzyme is implicated in congenital lipoid adrenal hyperplasia. A mitochondrial gene involved in electron transfer which codes for isovaleryl-CoA dehydrogenase is linked to the $15 \mathrm{q} 14-\mathrm{q} 15$ segment (10). Deficiency of this gene is the primary lesion in glutaric aciduria type II. The alpha polypeptide of hexosaminidase A is mapped to 15 q 23-q 24 (11). Deficiencies of this enzyme result in GM2 ganglioside storage disease. Fumarylacetoacetate hydrolase deficiency is implicated in hereditary tyrosinemia (type 1), and a segment of the gene for this recessive disorder is at $15 \mathrm{q}$ 23-q 25 (12). The mutation for xeroderma pigmentosa, complimentation group $\mathrm{F}$, is also assigned to chromosome 15 (13). Perhaps the most widely recognized gene on this chromosome is that for the Prader-Willi syndrome at the $15 \mathrm{q} 11-\mathrm{q}$ 13 region $(5,14)$. Discussion of the chromosome 15-linked neurodevelopmental disorders begins with this complex syndrome.

\section{PRADER-WILLI SYNDROME}

The Prader Willi syndrome (PWS) consists of obesity, hypotonia, mental retardation, hypogonadism, short stature, small distal extremities and eating disturbances $(15,16)$. Most PWS children are described as affectionate and happy until about age 3 when developmental delays become apparent in association with emotional lability and discontent (17). Mental retardation is common with the average IQ in the $50 \mathrm{~s}(18)$. In nonmentally retarded children, learning disabilities are present (19). Particularly severe deficits occur with tasks that involve auditory information processing (20). Other data indicates some PWS children have more difficulty with arithmetic skills (21). Consequences of intellectual and learning problems include impaired social and daily living skills $(21,22)$.

Other neuropsychiatric problems in PWS include impulsivity, aggressiveness, incessant skin picking and seizures $(22,23)$. Adolescents develop emotional problems ranging from agitated depression to acute psychosis $(22,23)$. Phobic behaviors and obsessive-compulsive disorders are also reported. Included in the 
obsessive-compulsive characteristics of PWS are eating disturbances such as gorging and nocturnal feeding $(22,23)$. PWS individuals demonstrate definite preferences for sweeter foods, and the strength of the food preference is directly related to the level of cognitive ability (24). The obesity can be very severe with associated abnormal glucose tolerance and frank diabetes.

Physical growth, maturational and sleep abnormalities are also prevalent. Shortness of stature contributes to disturbances of self-esteem $(22,25)$. Primary and secondary sexual maturation delays are also detrimental to self-concept. Although a specific brain lesion has not been identified, clomiphene stimulation studies provide evidence for a hypothalamic role in PWS (26). Hypothalamic dysfunction would also explain sleep disturbances usually manifesting as excessive daytime somnolence $(27,28)$. More recently, hypoventilation with obstructive sleep apnea leading to daytime somnolence is described $(29,30)$. Some PWS subjects develop sleep onset rapid eye movement (REM) sleep (SOREM) which is unrelated to daytime somnolence (31). Hypothalamic dysfunction is postulated to alter the circadian rhythmicity of REM propensity leading to the appearance of SOREM. PWS characteristics such as hypotonia in association with synchronized electroencephalogram (EEG) patterns are also demonstrated in experimental hypothalamic lesions (32). Factors such as obesity and scoliosis may further complicate the growth and sleep abnormalities (33).

Oculocutaneous albinism is a PWS component resulting from a reduction of melanocites in retinal and iris pigment epithelia of neuroepidermal origin (34). Misrouting of optic fibers with deviations 20 degrees or more at the chiasm with aberrant projections to the contralateral hemisphere are documented (35). The cortical cells do not receive normal binocular stimulation $(36,37)$. These factors produce aberrant information in the visual cortex and lateral geniculate nucleus (38). Increased light scattering in the eye of an infant with hypopigmentation and poor visual feedback due to nystagmus aggravates strabismus (39). The melanin pigment is thus likely a prerequisite for normal development of the optic system during embryogenesis. Misrouting may be due to a timing error in ontogeny $(38,40)$. This pigmentation defect may actually lie in the melanocytestimulating hormone receptors or post-receptor mechanisms involved in melanocyte-stimulating hormone action (41).

With the use of high resolution chromosome banding, various cytogenetic aberrations of PWS are identified in the $15 \mathrm{q} 11-\mathrm{q} 13$ regions $(7,14,42)$. More than $50 \%$ have a chromosome alteration involving these regions, most often a deletion, and less commonly a translocation. Cytogenetic findings in decreasing order of frequency in PWS include normal chromosomes, deletion 15 q 11-q 13, translocational deletion $15 \mathrm{p}$ and proximal $15 \mathrm{q}$, balanced translocation involving 15 , additional marker chromosome with resultant $15 p$ and/or proximal $15 q$ trisomy, tetrasomy, or pentasomy and mosaic deletion $15 \mathrm{q} 11-\mathrm{q} 13$ (22). The failure of detection of chromosomal abnormality in $40 \%$ of PWS cases is likely due to a submicroscopic deletion or heterozygoticity. Probes homologous to these regions from a fetal brain complementary DNA library indicate that the 
deleted genes of this region are expressed in the brain and reflective of its normal development (43).

\section{ANGELMAN SYNDROME}

The Angelman or "Happy Puppet" syndrome is characterized by mental retardation, epilepsy, ataxia, a large mandible, protruding tongue, abnormal pigmentation, hypotonia, coarse motor movements and a euphoric disposition with paroxysms of laughter (44). General behavioral features of Angelman syndrome include psychomotor retardation and developmental delay (45). Aggressiveness, short attention span, self-stimulatory behavior, hypersensitivity to sound, speech delays and poor eye contact are prominent. Structural imaging techniques have demonstrated generalized cortical atrophy. Seizures demonstrate a peculiar, unusual EEG pattern recognized as a key diagnostic feature. This characteristic pattern includes persistent, generalized, large amplitude slow wave activity not associated with drowsiness, prolonged runs of very large amplitude rhythmic slowing often more prominent anteriorly with periodic associated ill-defined spike-wave complexes, and spikes/sharp waves mixed with large amplitude components mainly seen posteriorly and most prominent with eye closure (46).

The associated states of spontaneous laughter and euphoria are striking. Paroxysms of loud, driven laughter with associated increases in psychomotor tone are displayed for up to several minutes. One report indicates a mother remarking that the laughter "is that of a more mature child," not something expected from an infant (47). The laughter has not been directly attributed to EEG abnormalities, but it is possible that gelastic epilepsy may play some role in this affective disturbance (48). Seizure discharges in the limbic system and temporal lobe can lead to euphoric dispositions, and lesions of the hypothalamus are sometimes associated with convulsive laughter (49).

Angelman syndrome is associated with a chromosomal deletion in the $15 \mathrm{q}$ $11-q 13$ region in $40 \%$ of cases (50). The specificity of the deletion within this region is not clearly differentiated from that of PWS. Genetic imprinting defined as the differential modification of parental contributions to the zygote resulting in the differential expression of information inherited from parents is hypothesized in the inheritance determination of Angelman syndrome and PWS as the sex of the parent transmitting the specific deletion in chromosome $15 \mathrm{q}$ 11-13 appears to have a major influence on the outcome. When the deletion occurs in the paternal chromosome, the result is PWS $(51,52)$, while maternal transmission of the same deletion results in Angelman syndrome $(53,54)$. The expression of a particular syndrome may not be entirely dependent on the presence of a deletion, but more importantly related to gene order and the consequent temporal expression of genes explaining why some cases lack evidence of a specific deletion (55). The presence of PWS with the lack of a deletion has also been explained by maternal heterodisomy where both copies of chromo- 
some 15 are of maternal origin (56). Thus, the absence of a paternal contribution whether by deletion or uniparental disomy leads to PWS, and it is entirely possible that paternal disomy could result in Angelman syndrome. Specific mechanisms involved in genetic imprinting are correlated to the degree of gene methylation $(57,58,59)$. It is not currently understood whether the sex-specific variations directly account for the imprinting mechanism or are merely reflective of an underlying process.

\section{DYSLEXIA}

Dyslexia is one of the most common conditions of childhood (60). Problems of dyslexic children include poor coordination, poor spatial reasoning, right-left confusion, poor temporal orientation, poor visual labelling, mixed cerebral dominance, linear tracking errors and failure to develop a leading eye $(61,62,63,64)$. Dyslexic children often demonstrate psychiatric problems such as Attention Deficit Hyperactivity Disorder, antisocial behavior, Tourette Syndrome, affective disturbances and anxiety disorders $(65,66)$.

Regional brain abnormalities are evident in certain dyslexics. An area on the posterior surface of the temporal lobe auditory cortex called the planum temporale has physically larger surface area on the left in $65 \%$ of normal nondyslexic subjects (67). In $25 \%$, symmetry is apparent while $10 \%$ show asymmetry favoring the right temporal plane. The reversal of normal hemispheric asymmetry is correlated with poor verbal skills and developmental dyslexia as confirmed by MRI (68). The reversed asymmetry of dyslexic subject MRI's reflect smaller right anterior width, bilaterally smaller insular regions, and a smaller left planum temporale consistent with abnormalities in brain areas important in language (69). Dyslexics also demonstrate histopathologic abnormalities including cortical ectopias, cortical neuronal dysplasias and polymicrogyria (70). These anomalies are located primarily in the left hemisphere around the Sylvian fissure. EEG and brain electrical activity mapping (BEAM) also indicate findings that are consistent with left brain dysfunction in dyslexic subjects $(71,72,73)$. Positron emission tomography (PET) correspondingly demonstrates hemispheric blood flow asymmetry, right flow greater than left (74).

Genetic analysis implicates chromosome 15 involvement in at least some familial reading disabilities. Linkage analysis of dyslexic subjects relates significantly to chromosome 15 short arm heteromorphisms $(60,75,76)$. Less significant correlations exist between chromosome 15 and dyslexics with prominent visual and spatial skill deficits (dyseidetic dyslexia). The highest correlations occur with subjects who primarily manifest semantic and linguistic problems (dysphonetic dyslexia). Other data has produced no correlation between chromosome 15 and dyslexia (77). Currently, it is suggested that dyslexia is a heterogenous disorder with at least 5 gene localizations (78). Thus, it is likely that only a subgroup of dyslexia derives from chromosome 15. 


\section{AUTISTIC DISORDERS}

Autistic disorders are characterized by qualitative impairment in social interaction, verbal and nonverbal communication, and imaginative ability (79). They initially present in early childhood as disorders of delayed development which continue pervasively. Characteristics include isolation and withdrawal from emotional and social contact, severe language disability with muteness or bizarre nonfunctional language and obsessive preoccupation with certain objects or routines. Stereotyped behaviors such as rocking, flapping and clapping are also evident. Autism was initially described as an exclusively psychiatric disorder, but ongoing research is increasingly substantiating a neurologic basis leading to its redefinition as a heterogenous neuropsychiatric syndrome.

Neuroanatomical data in autistics provides glimpses of possible pathogenic mechanisms. Neurohistological studies are scant, but one report demonstrates abnormalities of the hippocampus, amygdala, and cerebellum (80). Brain imaging using pneumoencephalography shows bilateral ventriculomegaly (81) and enlargement of the left temporal horn reflecting flattening and atrophy of the hippocampus (82). Studies with computerized tomography (CT) and magnetic resonance imaging (MRI) support these findings, additionally demonstrating enlargement of the fourth ventricle, hypoplasia of the neocerebellar vermal lobules VI and VII, and forebrain, basal ganglial, brainstem and thalamic structural abnormalities, implying that anatomical aberrations are not specifically localizable in autism $(83,84,85,86,87,88)$.

Electroencephalographic and evoked potential data also reflect abnormalities of brain function in autistic disorders. The average reported incidence of EEG abnormalities is $52 \%$ (89). These are usually diffuse abnormalities ranging from delta wave predominance to spike-wave complexes to hypsarrhythmic patterns, and these abnormalities reflect the associations of autism with epileptic disorders $(90,91)$. Brainstem auditory evoked potentials demonstrate longer transmission times and left brain dysfunction $(92,93)$. Auditory evoked potential P300's are abnormal, implicating processing defects in the limbic system $(94,95)$.

Neurochemical research has focused on hyperserotonemia reported in approximately one third of autistics (96). Antibodies to serotonin receptors have been identified in autism (97), and they may play a role in aberrant synaptogenesis as serotonin inhibits neurite growth (98). Various endocrinologic and enzyme studies demonstrate nonspecific abnormalities $(99,100)$. PET has demonstrated widespread metabolic aberrations in autistic brains consistent with impaired interaction of various brain regions $(101,102)$.

Autism is likely caused by a multitude of factors both genetic and environmental leading to the presenting behavioral disturbances. Family studies demonstrate the incidence of autism in siblings of autistics is in excess of population rates $(103,104)$. Twin studies are consistent with a genetic basis (105). Furthermore, cases that are discordant generally reflect a history of perinatal insult in the afflicted child implicating birth factors in the genesis of some autistic 
disorders. Other medical disorders associated with autism include congenital viral or bacterial infections, meningitis, encephalitis, tuberous sclerosis, phenylketonuria, neurofibromatosis, Cornelia de Lange syndrome, histidinemia, Rett syndrome and Fragile X syndrome (106). This information reflects that autistic behavior can be the result of various insults as well as developing as a primary genetic disorder.

One of the genetic associations of autism is with chromosome 15 partial trisomy. Numerous case reports describe autistic patients with small bi-satellited derivatives of chromosome $15(107,108,109,110,111,112)$. This abnormal structure has recently been postulated to derive from a replication error leading to the formation of a dicentric palindromic chromosome. Others have suggested that the structure represents an inverted duplication of regions 15 (pter-q13). Mechanisms such as parental inversion heterozygosity, translocation and U type exchange explain this hypothesis $(111,113)$. Additional clinical features include facial dysmorphism, mental retardation, seizures, hypotonia, and strabismus. Structural brain abnormalities findings such as left temporal horn enlargement are described (114). Thus, evidence suggests at least one subgroup of autistic disorders derive from chromosome 15 partial trisomy.

\section{HYPERLEXIA}

The term hyperlexia relates to advanced reading ability without previous practice in the context of poor comprehension, expressive language deficits and poor social interactions (115). It is an ability frequently associated with autism usually identified as a savant skill (116). However, some cases do not present with autism, and it has been suggested that hyperlexia may represent an extreme form of developmental surface dyslexia (117). This postulation follows from data indicating specific comprehension inabilities to understand large units of meaning (118). Alternatively, hyperlexia may represent an independent brain syndrome.

Highly focused selective attention involving right hemispheric processes leading to neurological precocity is postulated to account for declarative memory enhancement with dysfunctional procedural memory (115). The neuroanatomical substrate derives from diencephalic and bitemporal brain regions. Recently, hyperlexia has been described in a PWS patient (119). Given the described associations of PWS, dyslexia and autism to chromosome 15 , it is possible to speculate that hyperlexia may relate to a specific underlying genetic aberration explaining its overlapping and exclusivity with these chromosome 15 related disorders.

\section{RING 15 CHROMOSOME SYNDROME}

Individuals with ring 15 chromosome phenotypically present with growth deficiency, a triangular facies, digital anomalies, cafe au lait spots, microcephaly, 
skeletal asymmetry and cardiac defects $(120,121,122,123)$. Mental retardation in association with poor math skills and poor abstraction abilities are reported in conjunction with an observant, congenial, and euthymic affect in one patient (124). The chromosomal abnormality involves a deletion of the $15 \mathrm{q} 26.2$ to $\mathrm{q}$ terminal region. Ring 15 chromosome has certain phenotypic features similar to the Russell-Silver syndrome including growth deficiency, triangular facies, digital anomalies, asymmetry of growth and cafe au lait spots. In contrast, ring 15 chromosome patients are predominantly female while Russell-Silver subjects are predominantly male. Endocrinologic abnormalities such as growth hormone deficiency and hypopituitarism are more typical of the Russell-Silver syndrome $(125,126)$. It is likely that the phenotype is caused by multiple factors which lead to a common pattern of intrauterine growth retardation. The frequency of asymmetry implies differential effects before laterality is established $(127,128)$.

\section{TRISOMY 15 SYNDROME}

Duplication of $15 \mathrm{q}$ results in a syndrome characterized by growth retardation, synophrys, down slanting palpebral fissures, beaked nose, high arched palate and low-set ears. Central nervous system features include mental retardation, seizures, hypertonicity or hypotonicity, and hyperactivity (129). Trisomy 15 falls under the category of group D chromosomopathies (130). Other features include developmental retardation, feeding difficulty, failure to thrive, apnea, and deafness. Multiple congenital defects are usually incompatible with survival, and few infants survive the first six months of life.

Cerebellar heterotopia is a frequent neuropathologic feature of trisomy 15 (131). Of the three types of heterotopic formations encountered in the cerebellum, the most distinctive is composed exclusively of primitive granule cells (132). The other heterotopias are found to a limited extent with a variety of cerebral malformations, particularly pachygyria. Two cases have demonstrated a shortened corpus callosum and absence of the olfactory tracts. Other findings include a horseshoe shaped cerebrum with the basal ganglia bulging into an unpaired ventricle roof bordered by a transparent membrane.

\section{CONCLUSION}

In reviewing chromosome 15-linked neurodevelopmental disorders, it is obvious that some are better characterized than others in terms of their relation to this chromosome and in terms of their neurobehavioral characteristics. With the recent mandate to completely map the human genome, more information regarding the nature of chromosome 15 and its derived syndromes is expected (133). Current difficulties include developing the technology to enable the project to proceed at a reasonable cost as well as perceiving the ethical and legal implications that will follow (134). One technique being developed to accelerate the mapping process uses sequence tagged sites (STSs) which may be useful in 
rewriting all existing chromosome maps (135). More recently, investigators have narrowed the search for the Marfan syndrome gene to either chromosome 8 or 15 (136). With the additional advances that are expected to occur over the next decade, it is likely that a better understanding of the genetic mechanisms involved in chromosome 15-linked neurodevelopmental disorders will evolve.

\section{REFERENCES}

1. Mendelsohn ML, Mayall BH, Bogart E, et al: DNA content and DNA-based centromeric index of the 24 human chromosomes. Science 179:1126-1129, 1973

2. Miklos GLG, John B: Heterochromatin and satellite DNA in man: properties and prospects. Am J Hum Genet 31:264-280, 1979

3. Kurnit DM: Satellite DNA and heterochromatin variants: the case for unequal mitotic crossing-over. Hum Genet 47:169-186, 1979

4. Lejeune J, Maunoury C, Prieur M, et al: Translocation sauteuse (5p:15q), (8q:15q), (12q:15q). Ann Genet 22:210-213, 1979

5. Donlon TA, Lalande M, Wyman G, et al: Isolation of molecular probes associated with the chromosome 15 instability in the Prader-Willi syndrome. Proc Natl Acad Sci USA 83:4408-4412, 1986

6. Okamoto E, Miller DA, Erlanger BF, et al: Polymorphisms of 5-methylcytosine-rich DNA in human acrocentric chromosomes. Hum Genet 58:225-259, 1981

7. Schweizer D, Ambros P, Andrle M: Modification of DAPI banding on human chromosomes by prestaining with a DNA-binding oligopeptide antibiotic, Distamycin A. Exp Cell Res 111:327-332, 1978

8. Cox DW, Donlon TA: Report of the committee on the genetic constitution of chromosomes 14 and 15. Cytogenet Cell Genet 51:280-298, 1989

9. Chung BC, Matteson KJ, Voutilainen R, et al: Human cholesterol side-chain cleavage enzyme, P450scc: cDNA cloning assignment of the gene to chromosome 15, and expression in the placenta. Proc Natl Acad Sci USA 83:8962-8966, 1986

10. Barton DE, Yang-Feng TL, Matsubara Y, et al: The gene for isovaleryl-CoA dehydrogenase mapped to chromosome 15, region q14-q15. Cytogenet Cell Genet 46:578, 1987

11. Nakai H, Byers MG, Shows TB: Mapping HEXA to 15q23-q24. Cytogenet Cell Genet 46:667, 1987

12. Berube D, Phaneuf D, Tanquary RM, et al: Assignment of the fumarylacetoacetate hydrolase gene to chromosome 15q23-15q25. HGM10 A2687

13. Saxon PJ, Schultz RA, Stanbridge EJ, et al: Human chromosome 15 confers partial complementation of phenotypes to xeroderma pigmentosum group F cells. Am J Hum Genet 44:474-485, 1989

14. Latt SA, Tantravahi U, Nicholls R, et al: Mapping, characterization, and diagnostic utilization of 10 DNA segments from the proximal long arm of human chromosome 15. Cytogenet Cell Genet 46:644, 1987

15. Prader A, Lubhart A, Willi H: Ein syndrom von adipositas, kleinwuchs, kryptochismus und oligophrenie nach myotonicartigem zustand in neugenborenalter. Schweiz Med Wochenscher 86:1260-1261, 1956

16. Zellweger H: Diagnosis and therapy in the first phase of Prader-Willi syndrome, in Prader-Willi Syndrome. Edited by Holm VA, Sulzbacher S, Pipes PL. Baltimore, University Park Press, 1981 
17. LeConte JM: Social work strategies for families with Prader-Willi syndrome, in Prader-Willi Syndrome. Edited by Holm VA, Sulzbacher S, Pipes PL. Baltimore, University Park Press, 1981

18. Bray GA, Dahms WT, Swerdloff RH, et al: The Prader-Willi syndrome: A study of 40 patients and a review of the literature. Medicine 62:59-80, 1983

19. Sulzbacher S, Crnic KA, Snow J: Behavioral and cognitive disabilities in PraderWilli Syndrome, in Prader-Willi Syndrome. Edited by Holm VA, Sulzbacher S, Pipes PL. Baltimore, University Park Press, 1981

20. Gabel S, et al: Neuropsychological capacity of Prader-Willi children: General and specific aspects of impairment. Applied Research in Mental Retardation 7:459466,1986

21. Holm VA: The diagnosis of Prader-Willi syndrome, in Prader-Willi Syndrome. Edited by Holm VA, Sulzbacher S, Pipes PL. Baltimore, University Park Press, 1981

22. Cassidy SB: Prader-Willi Syndrome. Current Problems in Pediatrics 14:1-55, 1984

23. Whitman BY, Accardo P: Emotional symptoms in Prader-Willi syndrome adolescents. Am J Med Genet 28:897-905, 1987

24. Taylor RL, Caldwell ML: Type and strength of food preferences of individuals with Prader-Willi syndrome. J Ment Defic Res 29:109-112, 1985

25. Hall BD, Smith DW: Prader-Willi syndrome: a resume of 32 cases including an instance of affected lst cousins, one of whom is normal stature and intelligence. $J$ Pediatr 81:286-293, 1972

26. McGuffin WL, Rogol AD: Response to LH-RH and clomiphene citrate in two women with the Prader-Labhart-Willi syndrome. J Clin Endocrinol Metab 41:325331,1975

27. Laurance BM: Hypotonia, mental retardation, obesity and cryptorchidism associated with dwarfism and diabetes in children. Arch Dis Child 42:126-139, 1967

28. Zellweger H, Schneider HJ: Syndrome of hypotonia-hypomentia-hypogonadismobesity (HHHO) or Prader-Willi syndrome. Am J Dis Child 115:588-598, 1968

29. Orenstein DM, Boat TF, Stern RL, et al: Progesterone treatment of the obesity hypoventilation syndrome in a child. J Pediatr 90:477-479, 1976

30. Orenstein DM, Boat TF, Owens RP et al: The obesity hypoventilation syndrome in children with Prader-Willi syndrome: A possible role for familial decreased response to carbon dioxide. J Pediatr 95:765-767, 1980

31. Vela-Bueno A, Kales A, Soldatos CR et al: Sleep in Prader-Willi syndrome: clinical and polygraphic findings. Arch Neurol 41:294-296, 1984

32. McGinty DJ: Somnolence, recovery and hyposomnia following ventromedial diencephalic lesions in the rat. Electroencephalogr Clin Neurophysiol 26:70-79, 1969

33. Mezon BL, West P, Israels J, et al: Sleep breathing abnormalities in kyphoscoliosis. Am Rev Respir Dis 122:617-621, 1980

34. Hiltner HM, King RA, Riccardi VM, et al: Oculocutaneous albinoidism as a manifestation of reduced neural crest derivatives in the Prader-Willi syndrome. Am J Opthalm 94:328-337, 1982

35. Creel DJ, Bendel CM, Wiesner GL, et al: Abnormalities of the central visual pathways in Prader-Willi syndrome associated with hypopigmentation. New Engl J Med 314:1606-1609, 1986

36. Guillery RW: Visual pathways in albinos. Sci Am 230:44-54, 1974 
37. Creel D, Spekreijse H, Reits D: Evoked potentials in albinos: efficacy of pattern stimuli in detecting misrouted optic fibers. Electroencephalogr Clin Neurophysiol 52:595-603, 1981

38. Creel D, Witkop CJ Jr, King RA: Asymmetric visually evoked potentials in human albinos: evidence for visual system anomalies. Invest Ophthalmol 13:430-440, 1974

39. Jampolsky A: Unequal visual inputs and strabismus management: a comparison of human and animal strabismus, in Transactions of the New Orleans Academy of Ophthalmology Symposium on Strabismus St. Louis, CV Mosby, 1978

40. Taylor WOG: Visual disabilities of oculocutaneous albinism and their alleviation. Trans Ophthalmol Soc UK 98:423-445, 1978

41. Butler MG, Jenkins BB, Orth DN: Plasma immunoreactive betamelanocyte stimulating hormone (lipotropin) levels in individuals with Prader-Labhart-Willi syndrome. Am J Med Genet 28:839-844, 1987

42. Cassidy SB, Thuline HC, Holm VA: Deletion of chromosome 15 (q11-13) in a Prader-Labhart-Willi syndrome clinic population. Am J Med Genet 17:485-495, 1984

43. Ledbetter DH, Greenberg F, Holm VA, et al: Conference report: second annual Prader-Willi syndrome scientific conference. Am J Med Genet 28:779-790, 1987

44. Angelman H: Puppet children. A report of three cases. Dev Med Child Neurol 7:681-688, 1965

45. Hersh JH, Bloom AS, Zimmerman AW, et al: Behavioral correlates in the Happy Puppet syndrome: a characteristic profile? Devel Med Child Neurol 23:792-800, 1981

46. Boyd SG, Harden A, Patton MA: The EEG in early diagnosis of Angelman (Happy Puppet) syndrome. Eur J Pediatr 147:508-513, 1988

47. Elian M: Fourteen Happy Puppets. Clin Pediatr 14:902-908, 1975

48. Ford FR: The epilepsies and paroxysmal disorders of the nervous system, in Diseases of the Nervous System in Infancy, Childhood and Adolescence. Edited by Ford, FR. Springfield, Il., Charles C. Thomas, 1960

49. Chen R, Forster FM: Cursive epilepsy and gelastic epilepsy. Neurology 7:26-36, 1957

50. Pembrey M, Fennell SJ, Van Den Berghe J: The association of Angelman's syndrome with deletions within 15q11-13. J Med Genet 26:73-77, 1989

51. Butler MG, Palmer CG: Parental origin of chromosome 15 deletion in Prader-Willi syndrome. Lancet 1:1285-1286, 1983

52. Mattei JF, Mattei MG, Giraud F: Prader-Willi syndrome and chromosome 15: a clinical discussion of 20 cases. Hum Genet 64:356-361, 1983

53. Knoll JHM, Nicholls RD, Magenis RE, et al: Angelman and Prader-Willi syndromes share a common chromosome 15 deletion but differ in parental origin of the deletion. Am J Med Genet 32:285-290, 1989

54. Williams CA, Hendrikson JE, Cantu ES, et al: Angelman syndrome in a daughter with del (15) (q11-q13) associated with bradycephaly, hearing loss, enlarged foramen magnum and ataxia in the mother. Am J Med Genet 32:333-338, 1989

55. Williams CA, Zori RT, Stone JW, et al: Maternal origin of 15q11-13 deletions in Angelman syndrome suggests a role for genetic imprinting. Am J Med Genet $35: 350-353,1990$ 
56. Nicholls RD, Knoll JHM, Butler MG, et al: Genetic imprinting suggested by maternal heterodisomy in nondeletion Prader-Willi syndrome. Nature 342:281285,1989

57. Swain JL, Stewart TA, Leder P: Paternal legacy determines methylation and expression of an autosomal transgene: a molecular mechanism for parental imprinting. Cell 50:719-727, 1987

58. Reik W, Collick A, Norris ML, et al: Genomic imprinting determines methylation of parental alleles in transgenic mice. Nature 328:248-251, 1987

59. Sapienza C, Peterson AC, Rossant J, et al: Degree of methylation of transgenes is dependent on gamete of origin. Nature 328:251-254, 1987

60. Pennington BF, Smith DS: Genetic influences on learning disabilities and speech and language disorders. Child Dev 54:369, 1983

61. Hinshelwood J: Word-blindness and visual memory. Lancet 2:1564-1570, 1985

62. Benton A: Some conclusions about dyslexia, in Dyslexia: An Appraisal of Current Knowledge. Edited by Benton AL, Pearl D. New York, Oxford University Press, 1978.

63. Pavlides GT: Eye movements in dyslexia: their diagnostic significance. J Learn Disabil 18:42-48, 1985

64. Stein JF, Fowler S: A physiologic theory of visual dyslexia. Adv Neurol 42:233-245, 1984

65. Biederman J, Steingard R: Attention-Deficit Hyperactivity Disorder in adolescents. Psychiatric Annals 19:587-596, 1989

66. Hagin RH, Beecher R, Pagno G, et al: Effect of Tourette syndrome on learning, in Gilles de la Tourette Syndrome. Edited by Friedhoff JF, Chase TN. New York, Raven Press, 1982

67. Levitsky W: Human brain: left-right asymmetries in temporal speech region. Science 161:186-187, 1968

68. Rumsey JM, Dorwart R, Vermess M, et al: Magnetic resonance imaging of brain anatomy in severe developmental dyslexia. Arch Neurol 43:1045-1046, 1986

69. Hynd GW, Semrud-Clikeman M, Lorys AR, et al: Brain morphology in developmental dyslexia and attention deficit disorder/hyperactivity. Arch Neurol (in press)

70. Sherman GF, Rosen GD, Aboitiz F, et al: Developmental dyslexia: four consecutive patients with cortical anomalies. Ann Neurol 18:222-223, 1985

71. Duffy FH: Neurophysiological studies in dyslexia, in Education and the Brain. Edited by Chall JS, Mirsky AF. Chicago, University of Chicago Press, 1988

72. McAnulty GB: Brain electrical activity mapping (BEAM): the search for a physiological signature of dyslexia, in Dyslexia: A Neuroscientific Approach to Clinical Evaluation. Edited by Duffy FH, Geschwind N. Boston, Little Brown, 1985

73. Denckla MB, Bartels PH, Sandini G: Dyslexia: regional differences in brain electrical activity by topographic mapping. Ann Neurol 7:412-420, 1980

74. Gross-Glenn K, Dura R, Yoshii E, et al: PET-scan studies during a reading in dyslexic and non-dyslexic adults. Society for Neuroscience Abstract 12 (part 2): 1364,1986

75. Smith SD, Kimberling WJ, Pennington BF, et al: Specific reading disability: Identification of an inherited form through linkage analysis. Science 219:1345-1347, 1983

76. Fain PR, Kimberling WJ, Ing PS, et al: Linkage analysis of reading disability with chromosome 15. Cytogenet Cell Genet 40:625, 1985 
77. Bisgaard ML, Eiberg H, Moeller N, et al: Dyslexia and chromosome 15 heteromorphism: negative LOD score in a Danish material. Clin Genet 32:118-119, 1987

78. Lubs HA, Carland-Saucier K, Wen XL, et al: Genetic basis of developmental dyslexia: molecular studies, in Neuropsychological Foundations in Learning Disabilities. Edited by Hynd GW, Obrzut J. New York, Academic Press, (in press)

79. Mauren RG: Neuropsychology of autism. Psychiatr Clin North Am 9:367-380, 1986

80. Bauman M, Kemper TL: Histoanatomic observations of the brain in early infantile autism. Neurology 35:866-874, 1985

81. Aakrog T: Organic factors in infantile psychoses and borderline psychoses. Dan Med Bull 15:283-288, 1968

82. Hauser SL, DeLong GR, Rosman NP: Pneumographic findings in the infantile autism syndrome: a correlation with temporal lobe disease. Brain 98:667-688, 1975

83. Hier DB, LeMay M, Rosenbergher PB: Autism and unfavorable left-right asymmetries in the brain. J Autism Dev Disord 9:153-159, 1979

84. Gaffney GR, Kuperman S, Tsai LY, et al: Midsagittal magnetic resonance imaging of autism. Br J Psychiatry 151:831-833, 1987

85. Courchesne E, Yeung-Courchesne R, Press G, et al: Hypoplasia of cerebellar vermal lobules VI and VII in autism. N Engl J Med 318:1349-1354, 1988

86. Gaffney GR, Kuperman S, Tsai LY: Forebrain structure in infantile autism. J Am Acad Child Psychiatry 28:534-537, 1989

87. Gaffney GR, Kuperman S, Tsai LY: Morphological evidence for brainstem involvement in infantile autism. Biol Psychiatry 24:578-586, 1988

88. Jacobson R, LeCouteur A, Howlin P, et al: Selective subcortical abnormalities in autism. Psychol Med 18:39-48, 1988

89. DeMyer M, Hingtgen JN, Jackson RK: Infantile autism reviewed: a decade of research. Schizophrenia Bulletin 7:388-451, 1981

90. Waldo M, Cohen D, Caparulo E, et al: EEG profiles of neuropsychiatrically disturbed children. J Am Acad Child Psychiatry 17:656-670, 1978

91. Tsai LY, Tsai M, August G: Brief report: Implications of EEG diagnosis in the subclassification of infantile autism. J Autism Dev Disord 15:339-344, 1985

92. Skoff BF, Mirsky AF, Turner D: Prolonged brainstem transmission time in autism. Psychiatry Res 2:157-166, 1980

93. Fein D, Skoff B, Mirsky AF: Clinical correlates of brainstem dysfunction in autistic children. J Autism Dev Disord 11:303-305, 1981

94. Novick B, Vaughn GH Jr., Kurtzberg D, et al: An electrophysiologic indication of auditory processing deficits in autism. Psychiatry Res 3:107-114, 1980

95. Niwa S, Ohta M, Yamazaki K: P300 and stimulus evaluation process in autistic subjects. J Autism Devel Disord 13:33-42, 1983

96. Young JG, Kavanagh ME, Anderson GM, et al: Clinical neurochemistry of autism and associated disorders. J Autism Dev Disord 12:147-165, 1982

97. Todd RD, Ciaranello RD: Demonstration of inter- and intra-species differences in serotonin binding sites by antibodies from an autistic child. Proc Natl Acad Sci USA $82: 612-616,1985$

98. Haydon PG, McCobb DP, Kater SB: Serotonin selectively inhibits growth cone motility and synaptogenesis of specific identified neurons. Science 226:561-564, 1984 
99. Yamazaki K, Saito Y, Okada F, et al: An application of neuroendocrinological studies in autistic children and Heller's syndrome. Journal of Autism and Childhood Schizophrenia 5:323-332, 1975

100. Jackson MJ, Garrod J: Plasma, zinc, copper and amino acid levels in blood of autistic children. Journal of Autism and Childhood Schizophrenia 8:203-208, 1978

101. Rumsay JM, Duara R, Grady C, et al: Brain metabolism in autism: resting cerebral glucose utilization rates as measured with positron emission tomography. Arch Gen Psychiatry 42:448-455, 1985

102. Horwitz B, Rumsey JM, Grady C, et al: Interregional correlations of glucose utilization among brain regions in autistic adults. Ann Neurol 22:1 18, 1987

103. Lotter V: Epidemiology of autistic conditions in young children. I. Prevalence. Social Psychiatry 1:124-137, 1966

104. August G, Lockhart L: Familial autism and the fragile-X chromosome. J Autism Dev Disord 14:197-204, 1984

105. Folstein SE, Ruter ML: Autism: familial aggregation and genetic implications. J Autism Dev Disord 18:3-30, 1988

106. Prior MR: Biological and neuropsychological approaches to childhood autism. Br J Psychiatry 150:8-17, 1987

107. Zannotti M, Preto A, Giovanardi PR, et al: Extra dicentric 15pter-q21/22 chromosomes in five unrelated patients with a distinct syndrome of progressive psychomotor retardation, seizures, hyper-reactivity and dermatoglyphic abnormalities. J Ment Defic Res 24:235-242, 1980

108. Wisniewski L, Hassold T, Heffelfinger J, et al: Cytogenetic and clinical studies in five cases of inv dup (15). Hum Genet 50:259-270, 1979

109. Pfeiffer RA, Kessel E: Partial trisomy 15q1. Hum Genet 33:77-83, 1976

110. Rasmussen K, Nielsen J, Sillesen I, et al: A bisatellited marker chromosome in a mentally retarded girl with infantile autism. Hereditas 82:37-42, 1976

111. Schreck RR, Breg WR, Erlanger BF, et al: Preferential derivation of abnormal human G-like chromosomes from chromosome 15. Hum Genet 36:1-12, 1977

112. Sjostedt AW, Wahlstrom J: Autistic disorder and additional inv dup (15) (pter-q13). Am J Med Genet 35:448, 1990

113. VanDyke DL, Weiss L, Logan M, et al: The origin and behavior of two isodicentric bisatellited chromosomes. Am J Hum Genet 29:294-300, 1977

114. Hongell K, Iivanaien M: Partial trisomy 15 and temporal lobe syndrome in a retarded girl without gross malformations. Clin Genet 14:229-234, 1978

115. Goldberg TE: On hermetic reading abilities. J Autism Dev Disord 17:29-44, 1987

116. Rimland B: Savant capabilities of autistic children and their cognitive implications, in Cognitive Defects in the Development of Mental Illness. Edited by Serban G., New York, Brunner/Mazel, 1978

117. Pennington BF, Johnson C, Welsh MC: Unexpected reading precocity in a normal preschooler: implications for hyperlexia. Brain and Language 30:165-180, 1987

118. Snowling M, Frith U: Comprehension in "hyperlexic" readers. J Exp Child Psychol 42:392-415, 1986

119. Burd L, Kerbeshian J: Hyperlexia in Prader-Willi syndrome. Lancet 2:983-984, 1989

120. Fryns JP, Jaeker J, Devlieger H, et al: Ring chromosome 15 syndrome. Acta Paediatr Belg 34:47-49, 1981 
121. Yunis E, Leibovici M, Quintero L: Ring (15) chromosome. Hum Genet 57:207209, 1981

122. Silver HK, Kiyasu W, George J, et al: Syndrome of congenital hemihypertrophy, shortness of stature and elevated urinary gonadotropins. Pediatrics 12:368-376, 1953

123. Russell A: A syndrome of "intra-uterine" dwarfism recognizable at birth with craniofacial dysostosis, disproportionately short arms, and other anomalies (5 examples). Proc R Soc Med 47:1040-1044, 1954

124. Meincke P, Koske-Westphal T: Ring chromosome 15 in a male adult with radial defects: evaluation of the phenotype. Clin Genet 18:428-433, 1980

125. Hall JG: Microphallus, growth hormone deficiency and hypoglycemia in RussellSilver syndrome. Am J Dis Child 132:1149, 1978

126. Draznin MB, Stelling MW, Johanson AJ: Silver-Russell syndrome and craniopharyngioma. J Pediatr 96:887-889, 1980

127. Graham JM Jr, Hoehn H, Lin MS, et al: Diploid-triploidy-mixoploidy: clinical and cytogenetic aspects. Pediatr 68:23-28, 1981

128. Wilson GN, Barr M Jr: Trisomy 9 mosaicism: another etiology for the manifestations of Goldenhar syndrome. J Craniofacial Genet Dev Biol 3:313-316, 1983

129. Wyandt HE, Magenis RE, Hecht F: Abnormal chromosomes 14 and 15 in abortions, syndromes and malignancies, in New Chromosomal Syndromes. Edited by Yunis JJ. New York, Academic Press, 1977

130. Cohen PE, Phillips KG, Maunter LS: Multiple developmental anomalies and trisomy of a 13-15 group chromosome ('D' syndrome). Canad Med Ass J 87:709-712, 1962

131. Norman RM: Neuropathological findings in trisomies 13-15 and 17-18 with special reference to the cerebellum. Devel Med Child Neurol 8:170-177, 1966

132. Marin-Padilla M, Hoefnagel D, Benirschke K: Anatomic and histopathologic study of two cases of $\mathrm{D}_{1}(13-15)$ trisomy. Cytogenetics 3:258-284, 1964

133. Hall SS: Biologists zero in on life's very essence. Smithsonian 20:40-49, 1990

134. Marwick C: Technology, cost, cooperation, ethics challenges face genome mapping plan. JAMA 262:3247, 1989

135. Merz B: Promising new technique may accelerate genome mapping. JAMA 262: 2353, 1989

136. Randall T: Marfan syndrome gene search intensifies following identification of basic defect. JAMA 264:1642-1645, 1990 